\author{
Marian Reiff, Kvetoslava Surmanová \\ University of Economics in Bratislava, Slovak Republic \\ marian.reiff@euba.sk, kvetoslava.surmanova@euba.sk \\ Adam P. Balcerzak, Michał Bernard Pietrzak \\ Nicolaus Copernicus University, Poland \\ adam.balcerzak@umk.pl,michal.pietrzak@umk.pl
}

\begin{abstract}
The main aim of the article is to analyze differences in agriculture performance across the European Union countries in the years 2010-2013. Special attention was devoted to the results achieved by New Member States. The research was conducted with application of multiple criteria analysis tools: the method proposed by Hellwig and Ward's clustering method. The research was based on the analysis of the World Bank development indicators. It confirms the existence of significant disparity in the performance of agricultural sectors between the old and new member states of the EU .
\end{abstract}

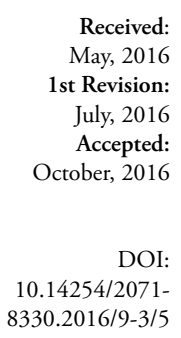

Keywords: Multiple Criteria Decision Analysis (MCDA), Hellwig Method, Cluster analysis, Economic performance, Agriculture

JEL Classification: C38, O13

\title{
INTRODUCTION
}

Creation of common agriculture policy has been one of the main objectives of the European Union founders. For five decades the expenditures on its realization had the largest share in the EU budget. In recent years Common Agriculture Policy (CAP) has been significantly reformed. As a result, with agricultural trade liberalization, the sector has shifted to more market orientation and less protection (Giannakis \& Bruggeman, 2015). However, an important objective of the CAP is still to mitigate differences in performance of agricultural sectors between the EU members. Additionally, despite the liberalization processes agriculture is still considered as the sphere of strategic interests of the EU and individual European governments both in the case of such big agricultural producers among old member states as France, Spain or Italy, but also in the new member states like Poland. Thus, the research on economic performance of European agriculture should be considered as an important field of interest.

Therefore, in this article the comparison of economic performance of agricultural sectors in the EU member states is performed. The research is conducted for the years 2010-2013. The first year of the research was chosen as it had been more than five years since the biggest European Union enlargement, 
which can be considered as a minimum time necessary for the adjustment of agricultural sector of Central European countries. The year 2013 is the last research year, since this is the last year for which the data is available for the whole set of countries under evaluation.

In this article the two main scientific aims are achieved. The first goal of the research is to propose a method for comparing economic performance of agricultural sector at national level. In this context, multiple criteria decision analysis (MCDA) methodology is applied. A ranking of countries was performed with application of Hellwig method. As the second objective of the article, the authors try to identify the group of countries that are similar to each other, but different from other groups of countries basing on the studied characteristics. For this purpose cluster analysis with application of Ward's method was used.

In the first part of the paper a review of previous research on the effectiveness of European agriculture is given with special consideration to the research, in which effectiveness of agriculture was treated as a complex and multivariate phenomenon. The second section is devoted to the presentation of the applied methodology. The third part of the paper has strictly empirical character. First, a ranking of countries was proposed. Then, it was supplemented with cluster analysis. The article is closing with short conclusions.

\section{REVIEW OF PREVIOUS RESEARCH}

The impacts of the EU enlargement and influence of the Common Agricultural Policy reforms measured by various agricultural performance measures have been the topics of profound research with application of quantitative methods both at aggregate macroeconomic and microeconomic level.

Latruffe (2010) reviews the literature on competitiveness, productivity and efficiency in the agricultural and agri-food sectors. The author clarifies concepts and terminology used in this area, and provides a critical assessment of approaches and indicators used in the literature to measure competitiveness, productivity and efficiency at sectorial and farm levels.

Dos Santos (2013) characterizes and segments the farms of the twenty-seven member states of the European Union. For this purpose, she adopted the technique of cluster analysis and clustering cases using segments of the farms, based on a sample of farms of the Farm Accountancy and Information. The results show the existence of four types of farms in the EU that are distinguishable by their structural characteristics, financial characteristics, and guidance and the importance of subsidies.

Spicka (2013) investigates the differences of farm income and its determinants between the old- (EU15) and the new EU member states (EU-12) before and after EU enlargements during 2001-2011. With cluster analysis the specific structural and economic features within the EU are identified. Author concludes that the rankings of the EU-27 countries changed after the EU enlargement. However, the European countries with highly intensive agriculture still rank the top positions. For example, the average labor input in the EU-12 is substantially higher than in the EU-15. This fact, together with the lower fixed capital consumption, points to the lower level of the technical equipment and farming technologies in the EU-12.

Carraresi and Banterle (2015) evaluates the EU countries' competitive performance at a sectorial level in the intra-EU market from 1995 to 2011 by comparing the food industry and agriculture; and assessing the effects of the EU expansion and economic crisis on country competitiveness. Results showed that although agriculture and the food industry in the EU are interconnected, they often reveal divergent trends in competitive performance. Germany and the Netherlands have profited the most from the opportunities resulting from the enlargement. On the contrary, France has lost competitiveness. A similar trend was found in Belgium. 
Giannaskis and Bruggeman (2015) investigate the factors that lie behind the differential performance of agriculture across the twenty-seven EU countries, based on gross-value-added and land and labor productivity indicators. Significant differences were revealed between the Northern-Central counties and the continental peripheries (Mediterranean, Eastern, and Northern Scandinavian). Authors have analyzed the factors behind this differential performance as human capital characteristics, environmental conditions and technical efficiency of crop production. Agricultural sectors characterized by a young and better trained farm population are more likely to attain high economic performance. On the other hand, the wheat and tomato yield variables highlight the importance of both environmental conditions and technical efficiency on farm economic performance.

Szabo and Grznár (2015) ranked individual EU countries according to the long-term average of the amount of their agricultural product per unit of area into seven segments. Conducted analysis showed strong links between the production and the fixed and variable assets, the levels of livestock, and the provided supports. The size of a business and the availability of labor force did not appear to have a significant influence on the performance of an average business in a country.

Svoboda et al. (2015) compare agricultural subsidies in the member states of the EU during 2004-2012 based on the database Farm Accountancy Data Network. The authors conclude that there has been a slight increase in operational subsidies. With the help of cluster analysis, the member states were divided into groups according to their operational subsidies, total production, and costs.

Pietrzak \& Walczak $(2014,2016)$ proved that the agrarian structure is one of the most important determinants of the development of agriculture in Poland. Ineffective agrarian structure with low concentration of land makes a significant barrier to the development of agriculture due to high production costs and generation of low income. In the research the authors applied spatial statistical measures and the Gini coefficient.

Due to the fact that effectiveness of agricultural sector is influenced by multivariate factors, in the case of the cited literature quantitative research was usually conducted with application of MCDA methods or cluster analysis. As a result, the study proposed in the current paper can be also placed in that methodological approach. It concentrates on the aggregate macroeconomic level.

\section{RESEARCH METHODOLOGY: MULTIPLE CRITERIA ANALYSIS}

Most of economic phenomena can be characterized as complex and multivariate factors from the perspective of description or quantification (Balcerzak, 2009; 2015; Biczkowski, et al. 2014; Pietrzak, et al. 2014; Jantoń-Drozdowska, and Majewska, 2015, 2016; Zielenkiewicz, 2014, 2015; Balcerzak and Pietrzak, 2016a, 2016b, 2016c, 2016d, 2016e; Pietrzak and Balcerzak, 2016a). As a result multiple criteria decision making (MCDM) or multiple criteria decision analysis (MCDA) methodology are currently commonly used in international comparative studies (Kuc, 2012a; Mościbrodzka, 2014; Jurkowska, 2014; Łyszczarz, 2016; Jurkowska, 2014).

Multiple criteria analysis methods can be divided into two groups. The first group allows to carry out ordering of objects from the worst to the best from the perspective of analyzed complex phenomena. Taxonomic measure of development proposed by Hellwig (Renigier-Biłozor and Biłozor, 2015; Pietrzak and Balcerzak, 2016b), which is applied in this article, can be found in this group. The second group of methods allows to classify analyzed objects to homogeneous subsets, where the objects are characterized with similar values of the features. In this group one can find cluster analysis with Ward's method as an example (Ward, 1963; Murtagh and Legendre, 2014; Kuc, 2012b). 
It should be emphasized that multiple criteria decision analysis methods provide useful tools, which can be effectively used not only in decision making process, but they can be universally applied in economic research. Their main advantage lies in their high cognitive values in explaining complex economic reality and their great application flexibility. These tools can be used to analyze most of economic phenomena. Additionally, the research can concentrate on any economic objects within the framework of undertaken problem.

\section{Taxonomic measure of development proposed by Hellwig}

The concept of taxonomic measure of development (TMD) was proposed by Zdzisław Hellwig in 1968 (Hellwig, 1968, 1972; see Balcerzak, 2016). The application of TMD allows to order analyzed objects (for example countries) based on the level of development of the phenomenon under evaluation. In order to use this measure the analyzed phenomenon is broken on the separate economic aspects, each of which describes a different part of the economic system. For each aspect a set of diagnostic variables that characterize the aspect and allow its description is selected. Then, based on the accepted diagnostic variables a synthetic variable (taxonomic measure of development) is calculated. It takes into account the impact of all determinants of examined economic phenomenon and allows to evaluate its level. The use of TMD in a spatial economic analysis enables to assess the current situation of the objects under study and to make their ranking from the worst to the best.

The procedure for obtaining TMD can be given in the following steps (Balcerzak, 2016; 2017; Balcerzak and Pietrzak, 2016e):

1. The research problem should be determined. Then, the examined phenomenon, a set of analyzed objects $O_{i}$ and a set of variables $Z_{j}$ characterizing the phenomenon should be adopted.

2. The diagnostic variables $Z_{j}$ should be standardized in order to obtain their comparability. As a result, standardized variables $S_{j}$ are obtained.

3. In the next step a pattern of development $W_{j}$ is determined. In the case of stimulants it is chosen in accordance with the principle of maximum value selection and opposite in the case of dis-stimulants. The stimulants can be defined as variables that support economic development of the phenomenon under evaluation and the dis-stimulants are the once that hamper it.

4. Then, with application of Euclidean distance for every $i$-object one should find distances $d_{i}$ from the pattern of economic development $W_{j}$.

In the last stage the value of $T M D_{i}$ for every $i$-object can be determined based on equation 1 .

$$
T M D_{i}=1-\frac{d_{i}}{d_{s}+2 s_{d}},
$$

where $T M D_{i}$ is the value of the measure for object $O_{i}, d_{i}$ is Euclidean distance of $\mathrm{i}$-object form the pattern of development, $d_{s}$ is an average distance of objects form the pattern of development, $s_{d}$ makes standard deviation of distances of the objects from the pattern of development.

$T M D_{i}$ determined in accordance with the described procedure is a normalized measure, which in most cases has values from zero to unity. Higher values of the measure indicate positive trends in the development of the examined phenomenon. 


\section{Cluster analysis}

Cluster analysis is a multivariate statistical technique that entails division of large group of objects into smaller and more homogeneous groups - clusters. In general terms, cluster analysis works with $N$ statistical objects while $k$ statistical characteristics are observed and measured. Clustering methods are based on similarity, respectively dissimilarity of the objects and based on these objects, data points are divided into clusters, which are mutually disjunctive. The objects assigned to every cluster are similar to each other in terms of the level of adopted variables. For the purpose of this paper agglomerative hierarchical clustering Ward's method (Ward, 1963) has been conducted, as it has been the most commonly used method in the studies reviewed in the previous section. Ward's method is based on least-squares criteria and minimizes the within-cluster sum of squares, thus maximizing the within-cluster homogeneity (Everitt et al., 2011). In this method, in the first stage of clustering, each analyzed object is considered as individual cluster and subsequently, these objects are grouped to superior cluster, which are grouped again based on the distance between them, while the objects with the smallest distance between are grouped together. On the highest level of clustering, all the statistical objects are joined into one cluster. For measurement of the distance between the objects the metric of Euclidian distance can be used

The process of Ward's method has an iterative character. It is repeated until each of all the clusters is formed into a single massive cluster.

The results of hierarchical clustering can be viewed through development tree or dendrogram. The root of the dendrogram represents the whole data set. The nodes within dendogram describe the extent to which the object relates. The results of the cluster analysis are dendrograms obtained by cross-section at different levels (Ward, 1963; Ivaničová, Kalužák, 2015; Reiff and Surmanová, 2016; Małkowska \& Głuszak, 2016).

\section{ECONOMIC PERFORMANCE OF AGRICULTURAL SECTOR OF EU COUNTRIES}

The characterized multiple criteria analysis methods were applied for comparative research on economic results of agricultural sector of the EU countries in the years 2010-2013. The research was conducted for 24 European Union member states. Luxemburg, Malta, Cyprus and Croatia were excluded from the research due to specific character of these economies, where truism, financial sector or production of luxurious goods have dominant role in GDP creation. In the same time agricultural sector has rather marginal role in these economies.

As it was presented in the review of previous research the economic performance of agricultural sector can be considered as multivariate phenomenon. Thus, in order to describe it, 6 diagnostic variables were used. The diagnostic variables with classification of their character and descriptive statistics are given in Table 1 . The variables $X_{1}$ to $X_{5}$ can be classified as stimulants. Their high values indicate higher effectiveness of agricultural sector of a given country. From the macroeconomic perspective last variable $X_{6}$ can be treated as dis-stimulant. From the perspective of developed industrial or knowledge-based economies high agriculture value added as a percentage of GDP can indicate ineffective structure of economy. In the case of highest developed economies high services and industrial production value added as a percentage of GDP is a standard.

The research is based on World Bank data. The data utilized for mulitiple criteria analysis were averaged across four year reference period (2010-2013) to mitigate specific effect in particular years, caused by fluctuations either in production due to for example bad weather conditions or in input, output prices on the world markets (Reiff and Surmanová, 2016). 
Table 1

Summary statistics of selected variables

\begin{tabular}{|l|c|c|c|c|c|c|c|}
\hline \multicolumn{1}{|c|}{ Variable } & Character & Mean & Median & Minimum & Maximum & $\begin{array}{c}\text { Standard } \\
\text { Deviation }\end{array}$ & $\begin{array}{c}\text { Coefficient } \\
\text { of Variation }\end{array}$ \\
\hline $\begin{array}{l}\mathrm{X}_{1}-\text { Crop production } \\
\text { index (2004-2006 } \\
=100)\end{array}$ & Stimulant & 98,47 & 96,35 & 68,23 & 138,65 & 15,05 & 0,15 \\
\hline $\begin{array}{l}\mathrm{X}_{2} \text { - Food production } \\
\text { index (2004-2006 } \\
=100)\end{array}$ & Stimulant & 99,78 & 100,22 & 83,72 & 125,00 & 10,39 & 0,10 \\
\hline $\begin{array}{l}\mathrm{X}_{3}-\text { Livestock } \\
\text { production index } \\
(2004-2006=100)\end{array}$ & Stimulant & 98,83 & 98,56 & 81,57 & 115,99 & 8,49 & 0,09 \\
\hline $\begin{array}{l}\mathrm{X}_{4}-\text { Cereal yield (kg } \\
\text { per hectare) }\end{array}$ & Stimulant & 5055,64 & 4917,86 & 1783,54 & 9058,98 & 1745,75 & 0,35 \\
\hline $\begin{array}{l}\mathrm{X}_{5}-\text { Agriculture } \\
\text { value added per } \\
\text { worker (constant } \\
\text { 2005 US\$) }\end{array}$ & Stimulant & 32232,27 & 25915,64 & 3158,29 & 135039,16 & 28585,62 & 0,89 \\
\hline $\begin{array}{l}X_{6}-\text { Agriculture, } \\
\text { value added (\% of } \\
\text { GDP) }\end{array}$ & Dis-stimulant & 2,59 & 2,28 & 0,31 & 6,28 & 1,45 & 0,56 \\
\hline
\end{tabular}

Source: own estimation based on World Bank data.

In the first step of the research TMD proposed by Hellwig was determined. Its values enabled to propose ranking of the countries based on economic results of their agricultural sectors. The results are given in Table 2 .

The research confirms that more than five years since the biggest EU enlargement significant heterogeneity between old and new members states is still present. The old member states can be considered as the leaders of the proposed ranking. Among the old member states only two Scandinavian countries Sweden and Finland, and two Southern European countries Greece and Portugal are characterized by relatively low level of TMD. To some extend these results should be expected, as the changes in agricultural sector, here improvement its effectiveness in the case of new member states, are usually gradual. On the other hand, among new member states relatively high positions in the proposed ranking were taken by two Baltic countries Estonia and Latvia. The ranking is closed with Central and Southern European economies such as Slovenia, Slovakia, Czech Republic, Poland, Bulgaria, Romania and Hungary.

Table 2

Ranking of the EU countries based on the economic results of agricultural sector

\begin{tabular}{|l|c|c|c|c|c|}
\hline \multicolumn{1}{|c|}{ Country } & Rank & TMD & Country & Rank & TMD \\
\hline \multicolumn{1}{|c|}{1} & 2 & 3 & 4 & 5 & 6 \\
\hline Netherlands & 1 & 0,593 & Lithuania & 13 & 0,276 \\
\hline Belgium & 2 & 0,453 & Sweden & 14 & 0,276 \\
\hline France & 3 & 0,431 & Slovenia & 16 & 0,269 \\
\hline Denmark & 4 & 0,413 & Portugal & 17 & 0,261 \\
\hline Germany & 5 & 0,411 & Finland & 18 & 0,257 \\
\hline Austria & 6 & 0,403 & Poland & & 0,242 \\
\hline
\end{tabular}




\begin{tabular}{|l|c|c|c|c|c|}
\hline \multicolumn{1}{|c|}{1} & 2 & 3 & 4 & 5 & 6 \\
\hline United Kingdom & 7 & 0,369 & Bulgaria & 19 & 0,217 \\
\hline Estonia & 8 & 0,326 & Czech Republic & 20 & 0,160 \\
\hline Spain & 9 & 0,309 & Greece & 21 & 0,100 \\
\hline Latvia & 10 & 0,303 & Slovak Republic & 22 & 0,034 \\
\hline Italy & 11 & 0,291 & Romania & 23 & 0,033 \\
\hline Ireland & 12 & 0,285 & Hungary & 24 & 0,023 \\
\hline
\end{tabular}

Source: own estimation based on World Bank data.

The proposed ranking should be additionally supplemented by pointing the subsets of relatively homogenous countries in relation to the values of the variables used in the analysis. Thus, in further analysis the cluster analysis was applied. The cluster analysis was performed in R-Cran. Ward's method characterized in previous section was applied here.

In the first step three classes of countries (Level 1) were selected based on the dendogram. The results are given in Figure 1 and in Table 3. In the first Class one can find Finland, Romania, Slovenia, Slovak Republic, Italy, Greece, Czech Republic, Hungary, Sweden. In the second Class there are Netherland, United Kingdom, Austria, Denmark, Belgium, France and Ireland. In the third Class the following countries were placed: Poland, Estonia, Lithuania, Portugal, Latvia, Bulgaria and Spain.

A comparison of three selected Classes with the ranking presented in Table 2 shows that within the Classes there are countries that occupy significantly different places in the ranking. For example, in the third Class one can find Latvia and Estonia, which are much higher in the ranking compared to other countries in this Class.

As a result, in the second stage a division of countries into six subsets (Level 2) was assumed. The dendogram with the results are given in Figure 2 and 3 and the Classes of countries are described in Table 3. The comparison of the obtained subsets with the ranking form Table 2 confirms that the assumption of division of the countries into 6 Classes is reasonable. The results of cluster analysis are consistent with application of the method proposed by Hellwig. All the countries in a given Class have relatively close positions in the ranking.

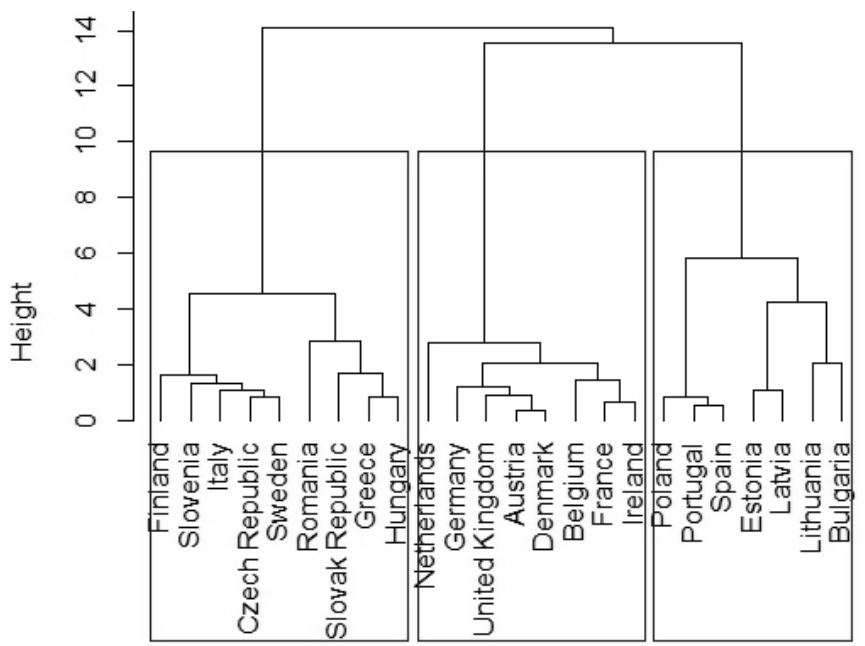

Figure 1. Dendogram presenting three classes based on the variables describing situation of agricultural sector (Level 1) Source: own estimation based on World Bank data. 


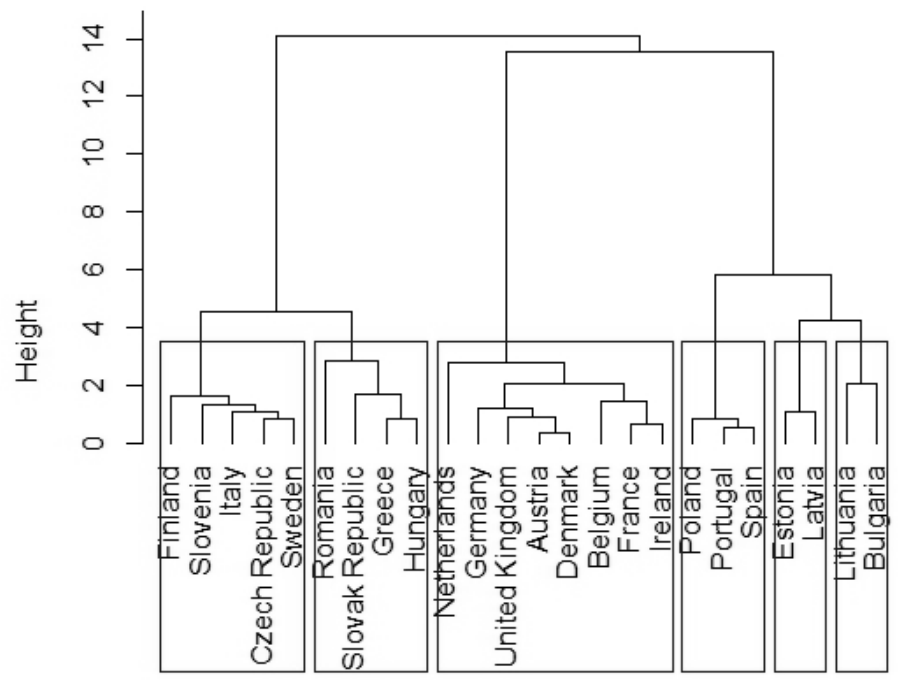

Figure 2. Dendogram presenting six classes based on the variables describing situation of agricultural sector (Level 2) Source: own estimation based on World Bank data.

Table 3

Classes of countries based on the dendograms from Figure 1 and 2

\begin{tabular}{|c|c|c|c|c|c|}
\hline \multicolumn{6}{|c|}{ Level 1} \\
\hline \multicolumn{2}{|c|}{ Class 1} & Class 2 & \multicolumn{3}{|c|}{ Class 3} \\
\hline \multicolumn{2}{|c|}{ Finland } & Netherlands & \multicolumn{3}{|c|}{ Poland } \\
\hline \multicolumn{2}{|c|}{ Slovenia } & Germany & \multicolumn{3}{|c|}{ Portugal } \\
\hline \multicolumn{2}{|c|}{ Italy } & United Kingdom & \multicolumn{3}{|c|}{ Spain } \\
\hline \multicolumn{2}{|c|}{ Czech Republic } & Austria & \multicolumn{3}{|c|}{ Estonia } \\
\hline \multicolumn{2}{|c|}{ Sweden } & Denmark & \multicolumn{3}{|c|}{ Latvia } \\
\hline \multicolumn{2}{|c|}{ Romania } & Belgium & \multicolumn{3}{|c|}{ Lithuania } \\
\hline \multicolumn{2}{|c|}{ Slovak Republic } & France & \multicolumn{3}{|c|}{ Bulgaria } \\
\hline \multicolumn{2}{|c|}{ Greece } & Ireland & & & \\
\hline \multicolumn{6}{|c|}{ Hungary } \\
\hline \multicolumn{6}{|c|}{ Level 2} \\
\hline Class 1 & Class 2 & Class 3 & Class 4 & Class 5 & Class 6 \\
\hline Finland & Romania & Netherlands & Poland & Estonia & Lithuania \\
\hline Slovenia & Slovak Republic & Germany & Portugal & Latvia & Bulgaria \\
\hline Italy & Greece & United Kingdom & Spain & & \\
\hline Czech Republic & Hungary & Austria & & & \\
\hline \multirow[t]{4}{*}{ Sweden } & & Denmark & & & \\
\hline & & Belgium & & & \\
\hline & & France & & & \\
\hline & & Ireland & & & \\
\hline
\end{tabular}

Source: own estimation based on World Bank data. 


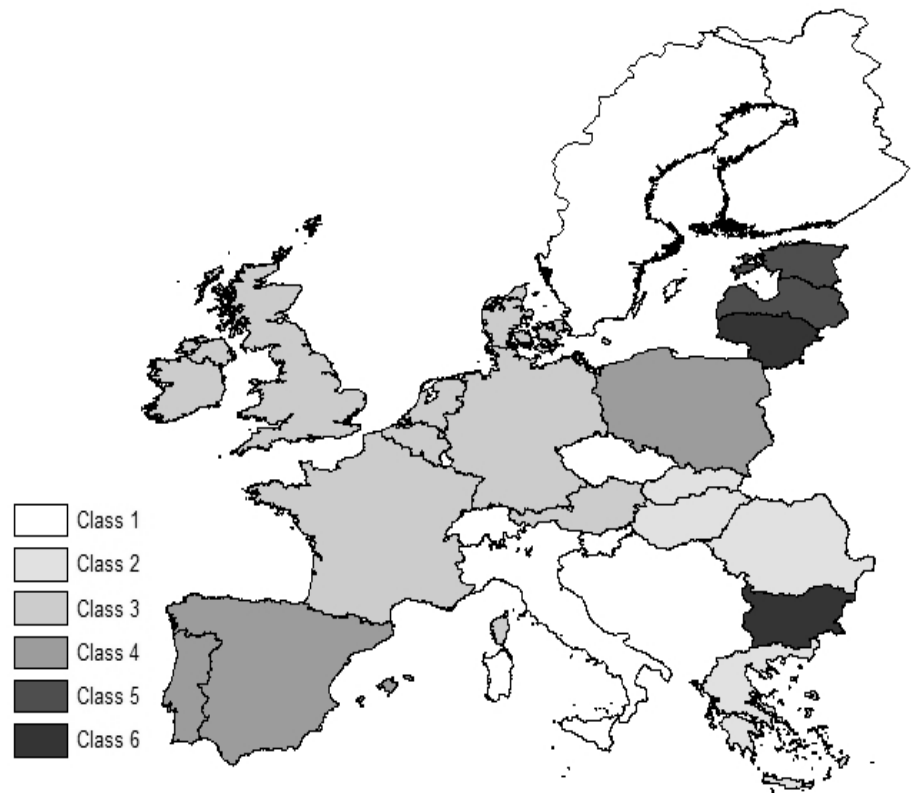

Figure 3. Grouping of countries into six classes (Level 2)

Source: own estimation based on World Bank data.

In the next step the differences between clusters were verified. To identify indicators that are of a significantly different level in one Class compared to another, the Kruskal-Wallis rank test was used. The KruskalWallis test is a rank-based nonparametric test that can be used to determine for every variable if there are statistically significant differences in an average for determined classes. The application of the test enables to verify if the values of the variables used in the research are significantly different for every class. As the Kruskal-Wallis test does not assume normality in the data and is much less sensitive to outliers, it can be used when these assumptions have been violated. The Kruskal-Wallis rank test was performed for six variables on Class 1, 2 and 3 defined by Level 1 and Class 1, 2, ., 6 defined by Level 2. The results are given in Table 4 . The analysis indicates that statistically significant differences between classes at the 0,05 level of significance are seen for all variables in the case of Level 1. In the case of level 2 averages between classes were significantly different for variables: $X_{1}, X_{2}, X_{3}, X_{4} X_{6}$. The exception here was variable $X_{5}$ - Agriculture value added per worker at Level 2. However, in the case of variable $X_{5}$ it should be noted that the p-value is 0.0538 . Thus, it is on the edge of significance. Raising the level of significance to $\alpha=0.1$ would mean that the average for variable $X_{5}$ is also significantly different for established groups.

As a conclusion, the results of Kruskal-Wallis test indicate that the variables used in the multiple criteria analysis were selected properly. Their values significantly differentiate determined classes. 
Table 4

Results of Kruskal-Wallis Test, Evidence of significant differences in average between Classes at level of significance $\alpha=0.05$

\begin{tabular}{|c|c|c|c|c|c|c|}
\hline $\boldsymbol{p}$-value & $\boldsymbol{X}_{\mathbf{1}}$ & $\boldsymbol{X}_{\mathbf{2}}$ & $\boldsymbol{X}_{\mathbf{3}}$ & $\boldsymbol{X}_{\mathbf{4}}$ & $\boldsymbol{X}_{\mathbf{5}}$ & $\boldsymbol{X}_{\mathbf{6}}$ \\
\hline Level 1 & 0,0004 & 0,0001 & 0.0012 & 0,0001 & 0,0216 & 0,0006 \\
\hline Level 2 & 0,0035 & 0,0015 & 0.002 & 0,0016 & 0,0538 & 0,0011 \\
\hline
\end{tabular}

Source: own estimation.

In the last step, for each of 6 classes (Level 2) an average values of the variables used to assess the effectiveness of agricultural sector were calculated. The average values for the variables allow to describe the main determinants of the position of the countries assigned to each class. The results are given in Table 5 .

\section{Table 5}

Average values of variables applied for multi criteria analysis of UE agriculture (Level 2)

\begin{tabular}{|cc|c|c|c|c|c|}
\hline Class & $\boldsymbol{X}_{\mathbf{1}}$ & $\boldsymbol{X}_{\mathbf{2}}$ & $\boldsymbol{X}_{\mathbf{3}}$ & $\boldsymbol{X}_{\mathbf{4}}$ & $\boldsymbol{X}_{\mathbf{5}}$ & $\boldsymbol{X}_{\mathbf{6}}$ \\
\hline Class 1 & 92,834 & 93,162 & 93,212 & 4877,046 & 57775,506 & 2,185 \\
\hline Class 2 & 85,764 & 87,689 & 89,151 & 4200,167 & 12783,462 & 4,386 \\
\hline Class 3 & 98,479 & 103,459 & 104,409 & 7274,908 & 43090,851 & 1,272 \\
\hline Class 4 & 102,744 & 103,604 & 103,643 & 3670,599 & 16178,440 & 2,660 \\
\hline Class 5 & 127,203 & 122,148 & 115,691 & 3031,042 & 8596,244 & 3,739 \\
\hline Class 6 & 126,720 & 112,426 & 94,184 & 3733,947 & 12732,635 & 4,561 \\
\hline
\end{tabular}

Source: own estimation.

In the ranking the highest positions are occupied by countries form class 3, Netherland, United Kingdom, Austria, Denmark, Belgium, France and Ireland, which are characterized by a high level of agriculture value added per worker (variable $X_{5}$ ) and the lowest share of agriculture value added in GDP (variable $X_{6}$ ).

Relatively high positions in the ranking are taken by the countries form class 5: Estonia and Latvia that have the highest levels of the variables $X_{1}, X_{2}$ and $X_{3}$, which confirms relative high performance of their agricultural sectors. However, in the same time these countries are characterized with the lowest level of agriculture value added per worker (variable $X_{5}$ ), which indicates relatively low labor productivity of their agriculture.

On the other hand, the highest level of agriculture value added per worker can be seen in the case of countries in class 1: Finland, Slovenia, Italy, Czech Republic and Sweden. In the same time these countries are characterized by a low level of variables $X_{1}, X_{2}, X_{3}$, which resulted in their relatively low positions in the final ranking.

The highest share agriculture value added in GDP could be seen in the case of countries in class 2 and 6. In class 2 one can find: Romania, Slovak Republic, Greece and Hungary. In the class 6 there are: Lithuania and Bulgaria. Almost four times higher agriculture value added in GDP in comparison with the countries from Class 3 indicates relatively high share of agriculture in product generation in the economies of these countries. In class 4 one can find: Poland, Portugal and Spain. These countries are characterized by an average level of all 6 variables, which is reflected in the rankings. 


\section{CONCLUSIONS}

In recent decades, significant reforms of the CAP and the enlargement of the EU have amplified research interest in studying the distinct differences in the performance of the agricultural sector in the EU countries. In addition to standard market self-regulation, the regulation of the industry by means of the CAP has played an important role in this sector. The CAP was created to regulate and support European agriculture. Inter alia, the aim of the CAP is to assist the development of agriculture of the EU member states and to mitigate differences in its performance (European Council, 2001).

In this contexts, the aim of the article was to study disparity in the agriculture and food industry sectors' performance in the EU countries during the period 2010 to 2013. Two methodological approaches: Taxonomic Measure of Development proposed by Hellwig and Ward's method were used. The results of both methods are consistent. They confirm the existence of significant disparity in the performance of agricultural sector between the old and new member states that joined the UE after the year 2004. Old EU member states Netherland, Belgium, France, Denmark, and Germany with hilly intensive agriculture rank the top five position. From new member states only Estonia and Latvia are among the top ten positions, remaining accessing countries are listed at last rank positions.

\section{REFERENCES}

Balcerzak, A. P. (2009). Effectiveness of the Institutional System Related to the Potential of the Knowledge Based Economy. Ekonomista, 6, pp. 711-739.

Balcerzak, A. P. (2015). Europe 2020 Strategy and Structural Diversity between Old and New Member States. Application of Zero-unitarizatin Method for Dynamic Analysis in the Years 2004-2013. Economics \& Sociology, 8(2), pp. 190210. DOI: dx.doi.org/10.14254/2071-789X.2015/8-2/14.

Balcerzak, A. P. (2016). Multiple-criteria Evaluation of Quality of Human Capital in the European Union Countries. Economics \& Sociology, 9(2), pp. 11-26. DOI: 10.14254/2071-789X.2016/9-2/1.

Balcerzak, A. P. \& Pietrzak, M. B. (2016a). Human Development and Quality of Institutions in Highly Developed Countries. In: M. H. Bilgin, H. Danis, E. Demir, and U. Can (Eds.). Financial Environment and Business Development. Proceedings of the 16th Eurasia Business and Economics Society. Springer International Publishing.

Balcerzak, A. P. \& Pietrzak, M. B. (2016b). Quality of Human Capital in European Union in the Years pp. 2004-2013. Application of Structural Equation Modeling. In Proceedings of the International Scientific Conference Quantitative Methods in Economics Multiple Criteria Decision Making XVIII. Vratna: Letra Interactive, pp. 7-12.

Balcerzak, A. P. \& Pietrzak, M. P. (2016c). Application of TOPSIS Method for Analysis of Sustainable Development in European Union Countries. In: T. Loster \& T. Pavelka (Eds.). The 10th International Days of Statistics and Economics. Conference Proceedings. September 8-10, 2016. Prague: Libuse Macakova, Melandrium, pp. 82-92.

Balcerzak, A. P. \& Pietrzak, M. B. (2016d). Structural Equation Modeling in Evaluation of Technological Potential of European Union Countries in the Years 2008-2012. In: M. Papież \& S. Śmiech (Eds.). The 10th Professor Aleksander Zelias International Conference on Modelling and Forecasting of Socio-Economic Phenomena. Conference Proceedings. Cracow: Foundation of the Cracow University of Economics, pp. 9-18. Retrieved from: http://econpapers.repec.org/bookchap/pesecchap/10.htm.

Balcerzak, A. P. \& Pietrzak, M. P. (2016e). Quality of Institutions for Knowledge-based Economy within New Institutional Economics Framework. Multiple Criteria Decision Analysis for European Countries in the Years 2000-2013. Economics \& Sociology, 9(4), DOI: 10.14254/2071-789X.2016/9-4/4.

Biczkowski, M., Muszyńska, M., Müller-Frączek, I., Pietrzak, M.B. and Wilk, J., (2014). The Delimitation of Bipolar Metropolitan Area Within the Kujawsko-pomorskie Region, Oeconomia Copernicana, 5(2), pp. 101-122. 
Carraresi, L., Banterle, A. (2015). Agri-food Competitive Performance in EU Countries: A Fifteen-Year Retrospective. International Food and Agribusiness Management Review, 18(2), pp. 37-62.

Dos Santos M. L. (2013). Segmenting Farms in the European Union. Agricultural Economics - Czech, 59, pp. 49-57.

Everitt, B.S., Landau, S., Leese, M. \& Stahl, D. (2011). Cluster Analysis. WileySeries in Probability and Statistics. John Wiley and Sons.

Giannakis, A., Bruggeman, E. (2015). The Highly Variable Economic Performance of European Agriculture. Land Use Policy, 45, pp. 26-35.

Giannakis, E., Bruggeman, A. (2015). The Highly Variable Economic Performance of European Agriculture. Land Use Policy, 45, pp. 26-35.

Hellwig, Z. (1968). Zastosowanie metody taksonomicznej do typologicznego podziału krajów ze względu na poziom ich rozwoju oraz zasoby i strukturę wykwalifikowanych kadr. Przeglad Statystyczny, 4, pp. 307-327.

Hellwig, Z. (1972). Procedure of Evaluating High-Level Manpower Data and Typology of Countries by Means of the Taxonomic Method. In: Z. Gostowski (Ed.). Towards a System of Human Resources Indicators for Less Developed Countries, Papers Prepared for a UNESCO Research Project. Wrocław: Ossolineum-The Polish Academy of Sciences, pp. 115-134.

Ivaničová, Z., Kalužák, L. (2015). Dynamika vývoja krajín Eurozóny na základe vybraných ukazovatelov. Ekonomické rozhlady, 44(4), pp. $476-492$.

Jantoń-Drozdowska, E. \& Majewska, M. (2015). Social Capital as a Key Driver of Productivity Growth of the Economy: Across-countries Comparison. Equilibrium. Quarterly Journal of Economics and Economic Policy, 10(4), pp. 61-83, DOI: http://dx.doi.org/10.12775/ EQUIL.2015.035.

Jantoń-Drozdowska, E., \& Majewska, M. (2016). Investment Attractiveness of Central and Eastern European Countries in the Light of New Locational Advantages Development. Equilibrium. Quarterly Journal of Economics and Economic Policy, 11(1), pp. 97-119, DOI: http://dx.doi.org/10.12775/EQUIL.2016.005.

Jurkowska, B. (2014). The Federal States of Germany - Analysis and Measurement of Development Using Taxonomic Methods. Oeconomia Copernicana, 5(3), pp. 49-73, DOI: http://dx.doi.org/10.12775/OeC.2014.019.

Kuc, M. (2012a). The Implementation of Synthetic Variable for Constructing the Sandard of Living Measure in European Union Countries. Oeconomia Copernicana, 3(3). pp. 5-19. DOI: http://dx.doi.org/10.12775/ OeC.2012.012.

Kuc, M. (2012b). The Use of Taxonomy Methods for Clustering European Union Countries Due to the Standard of Living. Oeconomia Copernicana, 3(2), pp. 5-23. DOI: http://dx.doi.org/10.12775/OeC.2012.006.

Latruffe, L. (2010). Competitiveness, Productivity and Efficiency in the Agricultural and Agri-food Sectors. OECD Food, Agriculture, and Fisheries Paper No 30. Paris: OECD Publishing.

Eyszczarz, B. (2016). Public-private Mix and Performance of Health Care Systems in CEE and CIS Countries. Oeconomia Copernicana, 7(2), pp. 169-185. DOI: http://dx.doi.org/10.12775/OeC.2015.011.

Małkowska, A., \& Głuszak, M. (2016). Pro-investment Local Policies in the Area of Real Estate Economics - Similarities and Differences in the Strategies Used by Communes. Oeconomia Copernicana, 7(2), pp. 269-283. DOI: http:// dx.doi.org/10.12775/OeC.2015.016.

Mościbrodzka, M. (2014). The Use of Methods of Multidimensional Comparative Analysis in Evaluation of the Standard of Living of Poland's Population in Comparison with Other Countries of the European Union. Oeconomia Copernicana, 5(3), pp. 29-47. DOI: http://dx.doi.org/10.12775/OeC.2014.018.

Murtagh, F., Legendre, P. (2014). Ward's Hierarchical Agglomerative Clustering Method: Which Algorithms Implement Ward's Criterion? Journal of Classification, 31(3), pp. 274-295.

Pietrzak, M. B., Walczak, D. (2014). The Analysis of the Agrarian Structure in Poland with the Special Consideration of the Years 1921 and 2002. Bulgarian Journal of Agricultural Science, 20(5), pp. 1018-1039. 
Pietrzak M. B., Wilk J.,. Kossowski T., Bivand R. (2014). The Identification of Spatial Dependence in the Analysis of Regional Economic Development - Join-count Test Application. In: M. Papież, S. Śmiech (Eds.), Proceedings of the 8th Professor Aleksander Zelias International Conference on Modelling and Forecasting of Socio-Economic Phenomena. Cracow: Foundation of the Cracow University of Economics, pp. 135-144.

Pietrzak, M. B. \& Balcerzak, A. P. (2016a). Quality of Human Capital and Total Factor Productivity in New EU Member States. In: T. Loster \& T. Pavelka (Eds.). The 10th International Days of Statistics and Economics. Conference Proceedings. September 8-10, 2016. Prague: Libuse Macakova, Melandrium, pp. 1492-1501.

Pietrzak, M. B., \& Balcerzak, A. P. (2016b). Assessment of Socio-Economic Sustainability in New European Union Members States in the years 2004-2012. In M. Papież \& S. Śmiech (Eds.). The 10th Professor Aleksander Zelias International Conference on Modelling and Forecasting of Socio-Economic Phenomena. Conference Proceedings. Cracow: Foundation of the Cracow University of Economics, pp. 120-129. Retrieved from: http://econpapers.repec.org/bookchap/pesecchap/11.htm.

Reiff, M., \& Surmanová, K. (2016). Cluster Analysis of EE Agriculture. In: Proceedings of the International Scientific Conference Quantitative Methods in Economics Multiple Criteria Decision Making XVIII. Vratna: Letra Interactive, pp. 322-326.

Renigier-Biłozor, M., \& Biłozor, A. (2015). Optimization of the Variables Selection in the Process of Real Estate Markets Rating. Oeconomia Copernicana, 6(4), pp. 139-157, DOI: http://dx.doi.org/10. 12775/OeC.2015.033

Spicka, J. (2013). The Economic Disparity in European Agriculture in the Context of the Recent EU Enlargements. Journal of Economics and Sustainable Development, 4, pp. 125-133

Svoboda, J. Lososová, J. Zdeněk, R. (2014). Analysis of Operating Costs of Subsidies in the Field of Agriculture of EU Countries. Agris on-line Papers in Economics and Informatics, 7, pp. 161-173.

Szabo, L, Grznár, M. (2015). Agriculture in the EU and Position of the Slovak Republic. Agricultural Econonomics Czech, 61, pp. 493-501.

Walczak D., Pietrzak, M. B., (2016). Analysis of Agrarian Structure in Poland in 1921 and 2002 based on the Example of Selected Districts. In: M. H. Bilgin, H. Danis, E. Demir, \& U. Can (Eds.). Business Challenges in the Changing Economic Landscape - Vol. 1, Springer, pp. 461-472.

Ward, J. H. (1963). Hierarchical Grouping to Optimize an Objective Function. Journal of American Statistical Association, 58(301), pp. 236-244.

World Bank 2010-2013. World Development Indicators. Retrieved form http://databank.worldbank.org/data/reports. aspx?source=world-development-indicators (9.01.2015).

Zielenkiewicz, M. (2014). Institutional Environment in the Context of Development of Sustainable Society in the European Union Countries. Equilibrium. Quarterly Journal of Economics and Economic Policy, 9(1), pp. 21-37, DOI: http://dx.doi.org/10.12775/EQUIL.2014.002.

Zielenkiewicz, M. (2015). The Role of the Level of Development, Geographical Factors, and Culture for the Efficacy of Economic Freedom. Equilibrium. Quarterly Journal of Economics and Economic Policy, 10(4), pp. 85-98, DOI: http://dx.doi.org/10.12775/ EQUIL.2015.036. 